\title{
Liposomal extended-release bupivacaine for postsurgical analgesia
}

\author{
This article was published in the following Dove Press journal: \\ Patient Preference and Adherence \\ 5 September 2013 \\ Number of times this article has been viewed
}

\section{Mark Lambrechts ${ }^{1,2}$ \\ Michael J O'Brien² \\ Felix H Savoie ${ }^{2}$ \\ Zongbing You ${ }^{1-3}$}

'Department of Structural and Cellular Biology, ${ }^{2}$ Department of Orthopaedic Surgery and Tulane Institute of Sports Medicine, ${ }^{3}$ Tulane Cancer Center, Louisiana Cancer Research Consortium, Tulane Center for Aging, Tulane Center for Stem Cell Research and Regenerative Medicine, Tulane University School of Medicine, New Orleans, Louisiana, USA
Correspondence: Zongbing You Department of Structural and Cellular Biology, Tulane University School of Medicine, I430 Tulane Avenue SL-49, New Orleans, LA 70I I2, USA

$\mathrm{Tel}+\mathrm{I} 5049880467$

Fax + I 504988 I687

Email zyou@tulane.edu
Abstract: When physicians consider which analgesia to use postsurgery, the primary goal is to relieve pain with minimal adverse side effects. Bupivacaine, a commonly used analgesic, has been formulated into an aqueous suspension of multivesicular liposomes that provide long-lasting analgesia for up to 72 hours, while avoiding the adverse side effects of opioids. The increased efficacy of liposomal extended-release bupivacaine, compared to bupivacaine hydrochloride, has promoted its usage in a variety of surgeries including hemorrhoidectomy, bunionectomy, inguinal hernia repair, total knee arthroplasty, and augmentation mammoplasty. However, like other bupivacaine formulations, the liposomal extended-release bupivacaine does have some side effects. In this brief review, we provide an update of the current knowledge in the use of bupivacaine for postsurgical analgesia.

Keywords: bupivacaine, liposome, analgesia, side effects, efficacy, patient satisfaction

\section{Introduction}

Postoperative pain management and minimal analgesic adverse side effects are critical factors in improving patient satisfaction. ${ }^{1,2}$ The systemic analgesic effects of opioids decrease pain in patients, but opioids are known to cause adverse side effects including nausea, dizziness, vomiting, urinary retention, constipation, pruritus, bradypnea, and sedation. ${ }^{3,4}$ These opioid-related symptoms often lead to a significant increase in total hospital cost and length of stay. ${ }^{5}$ Local analgesics have been utilized to avoid these side effects, but it is now known that they carry side effects of their own including but not limited to: chondrotoxicity, human tendon stem cell cytotoxicity, and intervertebral disk cytotoxicity. Furthermore, local analgesics have a short time of action, usually lasting less than 8 hours in adults. ${ }^{6,7}$ In order to prolong duration of action, catheters are inserted to the target site and connected to a local infusion pump, thereby analgesics are delivered to relieve pain with minimal adverse effects. ${ }^{8,9}$ However, the use of infusion pumps is often associated with tissue necrosis and wound infection. ${ }^{10}$ In order to provide long-lasting analgesia through single-dose administration, bupivacaine has been formulated with liposomes to create liposomal extended-release bupivacaine. One example of such a bupivacaine liposome injectable suspension is EXPAREL ${ }^{\circledR}$ (Pacira Pharmaceuticals, Inc., San Diego, CA, USA). EXPAREL ${ }^{\circledR}$ is an aqueous suspension of multivesicular liposomes (DepoFoam ${ }^{\circledR}$ drug delivery system; Pacira Pharmaceuticals, Inc.) containing bupivacaine at a concentration of $13.3 \mathrm{mg} / \mathrm{mL}$. After injection of EXPAREL ${ }^{\circledR}$ into soft tissue, bupivacaine is released from the multivesicular liposomes over a period of time. In this review, we will update the clinical use of EXPAREL ${ }^{\circledR}$ and related analgesics. 


\section{Bupivacaine liposome injectable suspension}

In 2006, Cocoran et $\mathrm{al}^{11}$ conducted a survey of 135 academic anesthesiology departments and found that $55 \%$ of them preferred bupivacaine hydrochloride $(\mathrm{HCl})$ as their local anesthetic of choice. Due to its novel design and slow release, EXPAREL ${ }^{\circledR}$ can produce local analgesia for up to 72 hours, ${ }^{12}$ about ten times longer than bupivacaine $\mathrm{HCl} .{ }^{13} \mathrm{EXPAREL}^{\circledR}$ has greater upfront costs than bupivacaine $\mathrm{HCl}$. The most recent wholesale acquisition cost for a vial of EXPAREL ${ }^{\circledR} 266 \mathrm{mg} / 20 \mathrm{~mL}$ is $\$ 14.25$ (pricing from December 1,2011 ) compared to a $10 \mathrm{~mL}$ vial of $0.25 \%$ bupivacaine $\mathrm{HCl}$ costing $\$ 0.291$ (pricing from April 1, 2012: of note, the wholesale acquisition cost represents published catalog price and may not be the actual transaction cost price). The overall costs for patients using EXPAREL ${ }^{\circledR}$ are likely cheaper than for bupivacaine $\mathrm{HCl}$ in patients who need long-term analgesia due to decreased need for opioids. ${ }^{14}$ To our knowledge, no study has directly evaluated hospital cost or length of stay between EXPAREL ${ }^{\circledR}$ and bupivacaine $\mathrm{HCl}$; however, it has been documented that the mean difference of cost and length of hospital stay between an EXPAREL ${ }^{\circledR}$-based multimodal analgesia regimen (\$8,766 and 2.0 days) and an opioid-based regimen ( $\$ 11,850$ and 4.9 days) was $\$ 3,084$ and 2.9 days in patients undergoing open colectomies. ${ }^{15}$

Bupivacaine blocks sodium channels during an action potential, thus inhibiting generation and conduction of nerve impulses initiated by painful stimuli. ${ }^{16}$ Chahar and Cummings ${ }^{17}$ described in detail the structure, pharmacodynamics, and pharmacokinetics of this new liposomal bupivacaine. The extended-release advantage of EXPAREL ${ }^{\circledR}$ has promoted its widespread use in surgical procedures such as hemorrhoidectomy, bunionectomy, inguinal hernia repair, total knee arthroplasty, augmentation mammoplasty, and colectomy.

\section{Patient satisfaction and efficacy}

Patients will have little tolerance of a drug that has numerous adverse effects, making this a necessary parameter in comparing drug choice. Baxter et $\mathrm{al}^{18}$ and Viscusi et al ${ }^{19}$ retrospectively reviewed ten randomized, double-blinded studies to determine total adverse events after administration of $66 \mathrm{mg}$ to $532 \mathrm{mg}$ EXPAREL $^{\circledR}$ or $75 \mathrm{mg}$ to $200 \mathrm{mg}$ bupivacaine $\mathrm{HCl}$. Adverse events (AEs) were classified as wound complications, wound healing times, and wound scarring. Local AEs, including erythema, drainage, edema, and induration, were noted over 36 days. Baxter et al found that the percent incidence of AEs was similar across both modes of analgesia. ${ }^{18}$ AEs occurred in 9\%-20\% of 823 patients who received EXPAREL ${ }^{\circledR}$ compared to $8 \%-19 \%$
AEs in 446 patients who were treated with bupivacaine $\mathrm{HCl}$. Furthermore, wound-healing and bone-healing at doses up to $532 \mathrm{mg}$ EXPAREL ${ }^{\circledR}$ appeared similar to the bupivacaine $\mathrm{HCl}$ group. In contrast, Viscusi et al noted $62 \%$ of patients had AEs when they received EXPAREL ${ }^{\circledR}$, compared to $75 \%$ of patients who received bupivacaine $\mathrm{HCl}$ and $43 \%$ of the patients treated with placebo. ${ }^{19}$ Furthermore, serious AEs were noted in $2.7 \%$ of EXPAREL ${ }^{\circledR}$ users versus $5.4 \%$ of bupivacaine $\mathrm{HCl}$ users.

Dasta et $\mathrm{al}^{20}$ examined the postsurgical use of EXPAREL ${ }^{\circledR}$ at doses $\leq 266 \mathrm{mg}$ versus bupivacaine $\mathrm{HCl}$ at doses $\leq 200 \mathrm{mg}$. A total of nine double-blinded studies were pooled and analyzed from five surgical procedures including inguinal hernia repair, total knee arthroplasty, breast augmentation, hemorrhoidectomy, and bunionectomy. Patient outcomes were evaluated by cumulative pain intensity scores (area under the curve) based on a numerical rating scale throughout a period of 72 hours after surgery. The cumulative pain intensity score was found to be lower in patients using EXPAREL ${ }^{\circledR}$ than in patients using bupivacaine $\mathrm{HCl}$ (283 versus $329, P=0.039$ ). The median time until opioid rescue was 10 hours when using EXPAREL $^{\circledR}$, compared to 3 hours when using bupivacaine $\mathrm{HCl}$. Furthermore, opioid usage was decreased from $19 \mathrm{mg}$ in the bupivacaine $\mathrm{HCl}$ group to $12 \mathrm{mg}$ in the EXPAREL ${ }^{\circledR}$ group, suggesting a decrease in the opioid-related AEs.

By focusing on a dose of $266 \mathrm{mg}$ EXPAREL $^{\circledR}$ post hemorrhoidectomy, Haas et $\mathrm{al}^{21}$ found that the median time until opioid rescue was 19 hours, much longer than the 8 hours noted in the patients who received bupivacaine $\mathrm{HCl}$ $(P=0.05)$. AEs related to opioids were also found in $35 \%$ of the patients injected with bupivacaine $\mathrm{HCl}$ compared to only $4 \%$ of the patients injected with $266 \mathrm{mg}$ EXPAREL ${ }^{\circledR}$.

Bramlett et $\mathrm{al}^{22}$ compared the efficacy and safety of $150 \mathrm{mg}$ bupivacaine $\mathrm{HCl}$ with 1:200,000 epinephrine versus EXPAREL ${ }^{\circledR}$ at doses of $133 \mathrm{mg}, 266 \mathrm{mg}, 399 \mathrm{mg}$, and $532 \mathrm{mg}$, following total knee arthroplasty. The doubleblinded study found that the cumulative pain intensity scores through 4 days postsurgery were 20.7, 19.5, 18.8, and 19.1, for using EXPAREL ${ }^{\circledR}$ at doses of $133 \mathrm{mg}, 266 \mathrm{mg}, 399 \mathrm{mg}$, and $532 \mathrm{mg}$, respectively, compared to a cumulative pain intensity score of 20.4 when using bupivacaine $\mathrm{HCl}$ at a dose of $150 \mathrm{mg}$. Smoot et $\mathrm{al}^{23}$ conducted a randomized, doubleblinded study on 136 patients who underwent submuscular augmentation mammoplasty and compared the pain and opioid usage after a single $600 \mathrm{mg}$ dose of EXPAREL ${ }^{\circledR}$ and a single $200 \mathrm{mg}$ dose of bupivacaine $\mathrm{HCl}$. The mean cumulative pain scores (numerical rating scale with activity through 3 days) were 441.5 using EXPAREL ${ }^{\circledR}$ and 468.3 
using bupivacaine $\mathrm{HCl}(P=0.3999)$. EXPAREL ${ }^{\circledR}$ usage was associated with a significant decrease in opioids consumed during the first 24 hours $(P=0.0211)$ and 48 hours $(P=0.0459)$. Bergese et $\mathrm{al}^{24}$ analyzed a pool of 823 patients, from ten randomized, double-blinded studies, who were injected via local wound infiltration sites with EXPAREL ${ }^{\circledR}$ (doses varied from $66 \mathrm{mg}$ to $532 \mathrm{mg}$ ). Another group of 446 patients were injected with bupivacaine $\mathrm{HCl}$ at doses ranging from $75 \mathrm{mg}$ to $200 \mathrm{mg}$, and 190 patients were included in a placebo group. The pain intensity scores were lower in the EXPAREL $^{\circledR}$ group than in the placebo group in 16 of the 19 treatment arms analyzed $(P<0.05)$. In contrast, only five of the 17 treatment arms using bupivacaine $\mathrm{HCl}$ had a lower pain score than the placebo group $(P<0.05)$.

The efficacy of EXPAREL ${ }^{\circledR}$ was further supported by the mean time until opioid usage, consumption of opioids, and patient/care provider satisfaction with postsurgical analgesia. Golf et $\mathrm{al}^{25}$ compared EXPAREL ${ }^{\circledR}$ to placebo in a randomized study of 193 patients who had undergone bunionectomy. Ninety-six patients were placed in the placebo group, while 97 patients were administered $120 \mathrm{mg}$ of EXPAREL ${ }^{\circledR}$ through wound infiltration before closure. Over the first 24 hours and 36 hours, EXPAREL ${ }^{\circledR}$ significantly decreased pain compared to the placebo ( $P=0.0005$ and $P<0.0229$, respectively). Patients also avoided opioid usage at a greater rate than placebo when injected with EXPAREL ${ }^{\circledR}(7.2 \%$ versus $1 \%$ of patients, $P<0.0404)$. The median time until first opioid usage was prolonged by EXPAREL ${ }^{\circledR}$ compared to placebo (7.2 hours versus 4.3 hours, $P<0.0001)$. Gorfine et $\mathrm{al}^{26}$ conducted a double-blinded study with 186 patients, comparing EXPAREL ${ }^{\circledR}$ and placebo to assess postsurgical analgesia benefits. Pain intensity scores were lower in patients using EXPAREL ${ }^{\circledR}$ than in patients using placebo (141.8 versus $202.5, P<0.001)$. The mean usage of opioids over the first 72 hours was $22.3 \mathrm{mg}$ and $29.1 \mathrm{mg}$ for EXPAREL ${ }^{\circledR}$ and placebo groups, respectively $(P<0.0006)$. The median time until first opioid usage was 14.3 hours and 1.2 hours for the EXPAREL ${ }^{\circledR}$ and placebo groups, respectively. Most importantly, 95\% of patients in the EXPAREL ${ }^{\circledR}$ group were satisfied with their postsurgical analgesia, compared to $73 \%$ of patients in the placebo group $(P=0.0007)$. Based on the aforementioned studies, a comparison between EXPAREL ${ }^{\circledR}$ and bupivacaine $\mathrm{HCl}$ is summarized in Table 1.

\section{Systemic toxicities}

It is well documented that bupivacaine $\mathrm{HCl}$ can prolong QTc intervals (corrected intervals between the $\mathrm{Q}$ wave and T wave) and cause ventricular arrhythmias through potassium channel blockade. ${ }^{27-29}$ Borgeat et $\mathrm{al}^{30}$ also noticed an increase in the PQ interval within 15 minutes of $5 \mathrm{mg} / \mathrm{mL}$ injection of bupivacaine. The prolongation continued for 1 hour, when the PQ interval shortened to near normal ranges. Furthermore, they reported no change in QRS, QT, or QTc intervals. However, current research suggests that EXPAREL ${ }^{\circledR}$ has a better cardiac safety profile compared to standard bupivacaine injections. Naseem et $\mathrm{al}^{31}$ conducted a study in healthy patients, evaluating their QTc intervals at doses of $300 \mathrm{mg}, 450 \mathrm{mg}, 600 \mathrm{mg}$, and $750 \mathrm{mg}$ EXPAREL ${ }^{\circledR}$. The alteration of QTc intervals by EXPAREL ${ }^{\circledR}$ was compared to changes caused by moxifloxacin. The authors found that moxifloxacin induced QTc prolongation of 12 seconds with a two-sided $95 \%$ confidence interval above 10 seconds. EXPAREL ${ }^{\circledR}$ at doses of $300 \mathrm{mg}, 450$ $\mathrm{mg}, 600 \mathrm{mg}$, and $750 \mathrm{mg}$ caused the QTc interval to decrease by $2.24,2.45,3.6$, and 7.67 milliseconds, respectively. Only the $600 \mathrm{mg}$ dose fell short of the significance level of the two-sided $95 \%$ confidence interval. This study suggests that EXPAREL $^{\circledR}$ reduces QTc intervals and may be a safer, longlasting alternative to bupivacaine $\mathrm{HCl}$.

Bupivacaine also carries significant risk of toxicity in the central nervous system if given in overdose or injected intravenously. Feldman et $\mathrm{al}^{32}$ found that the mean dosage to cause seizures in dogs after intravenous bupivacaine injection was as low as $8.6 \mathrm{mg} / \mathrm{kg}$, leading to a mean duration of seizure of 307 seconds. Since substantial plasma concentrations of bupivacaine are required to cause toxicities in the central nervous system, it should be of minimal concern if the local anesthetic is properly administered.

\section{Local toxicities}

Intervertebral disk cell cytotoxicity, myocyte toxicity, chondrotoxicity, and granulomatous inflammation are potential localized side effects of EXPAREL ${ }^{\circledR}$ injection. The most

Table I Comparison between EXPAREL ${ }^{\circledR}$ and bupivacaine $\mathrm{HCl}$

\begin{tabular}{llll}
\hline Formulation & Costs & $\begin{array}{l}\text { Pain intensity } \\
\text { scores }\end{array}$ & $\begin{array}{l}\text { Time until opioid } \\
\text { events }\end{array}$ \\
\hline EXPAREL $^{\circledR}$ & $\$ 14.25 / 20 \mathrm{~mL}$ & $283^{*}, 441.5^{\dagger}$ & $10^{*}, 19^{\#}$ \\
Bupivacaine $\mathrm{HCl}$ & $\$ 0.291 / 10 \mathrm{~mL}$ & $329^{*}, 468.3^{\dagger}$ & $9-20 \%^{\pi}, 6 \%^{\lambda}$ \\
\hline
\end{tabular}

Notes: ${ }^{\pi}$ Baxter et al; ${ }^{18} \lambda$ Viscusi et al; ${ }^{19} *$ Dasta et al; ${ }^{20}{ }^{*}$ Haas et al $;{ }^{21}+$ Smoot et al. ${ }^{23}$

Abbreviation: $\mathrm{HCl}$, hydrochloride. 
benign of these side effects is a small amount of granulomatous inflammation due to liposome degradation. ${ }^{10,33}$

Chondrotoxicity appears to be a much more salient problem in intra-articular usage of EXPAREL ${ }^{\circledR}$, like other local anesthetics, which is why Pacira Pharmaceuticals, Inc., does not recommend intra-articular use of EXPAREL ${ }^{\circledR}$. While an intra-articular injection of $0.125 \%$ bupivacaine does not induce chondrocyte death, $0.25 \%$ bupivacaine is significantly chondrotoxic after 60 minutes exposure. ${ }^{34}$ Alarmingly, Chu et al ${ }^{35}$ reported that an intra-articular injection of $0.5 \%$ bupivacaine led to a $50 \%$ loss in chondrocyte density with no obvious cartilage loss. Chondrotoxicity has been investigated most extensively in the glenohumeral joint. Wiater et $\mathrm{al}^{36}$ conducted a prospective level II cohort study analyzing 375 cases of arthroscopic shoulder surgeries to assess chondrolysis from intra-articular injections of bupivacaine and lidocaine. Survival analysis was implemented to assess chondrocyte death, and the strength of these results was computed as hazard ratios estimated from the Cox proportional hazard model. Both adjusted and unadjusted Cox proportional hazard models were used to account for the variability due to patient age and the date of surgery. Of the 375 surgeries, 49 patients suffered from chondrolysis, with half being identified within the first 18 months postsurgery. Each patient was known to have postsurgical intra-articular injection of bupivacaine or lidocaine ( $P<0.001$, Cox regression). No chondrolysis was found in patients who did not receive intra-articular injections of local anesthetics. In another study, Anderson et $\mathrm{al}^{37}$ reported 18 individuals diagnosed with glenohumeral chondrolysis, all of them had received intra-articular injections of bupivacaine through an intra-articular pain pump catheter. No thermal energy was used as part of their operation. Decreased range of motion was also noted as a result of the surgeries. These studies caution against intra-articular injection of EXPAREL ${ }^{\circledR}$ or other local anesthetics. This precaution is further supported by a study of patients with damaged cartilage. ${ }^{38} \mathrm{~A}$ recent in vitro study has shown that hyaluronan can prevent chondrocyte death caused by bupivacaine at supraphysiological temperatures. ${ }^{39}$ However, whether coinjection of hyaluronan and bupivacaine intra-articularly may alleviate bupivacaine's chondrotoxicity awaits further evidence from in vivo studies.

It should be noted that the use of EXPAREL ${ }^{\circledR}$ has not been approved by the US Food and Drug Administration for spinal usage. To the best of our knowledge, no studies have been published in evaluating the use of EXPAREL ${ }^{\circledR}$ versus standard bupivacaine as a local anesthetic in spinal procedures. However, bupivacaine $\mathrm{HCl}$ is an anesthetic used in spinal procedures, and in vitro studies have shown that it is toxic in a dose- and time-dependent manner. Doses as small as $0.25 \%$ bupivacaine induced nearly $100 \%$ cell death in the annulus pulposus and nucleus pulposus cells of intervertebral disks. ${ }^{40,41}$ These results have been supported by the results from an ex vivo mouse model in which bupivacaine reduced both cell viability and synthesis of matrix proteins. ${ }^{42}$ Coinjection of $1 \mathrm{mg}$ triamcinolone with bupivacaine has been shown to have a protective effect on intervertebral disk cells. ${ }^{43}$

Bupivacaine is also known to cause acute skeletal muscle degeneration with a slow but nearly maximal regeneration after 2 months. ${ }^{44}$ A possible mechanism of myotoxicity is through induction of calcium release from the sarcoplasmic reticulum, while concurrently inhibiting calcium reuptake. ${ }^{45}$ Although the muscle tissue is capable of regeneration after injection of bupivacaine at doses as high as $0.75 \%$, late-stage scarring has been found. This damage is dose-dependent because injection of bupivacaine at doses $<0.38 \%$ does not cause any long-term damage. ${ }^{46}$ Although most studies typically focus on adults, myonecrosis may be even more pronounced in children due to oxidative mitochondrial changes. ${ }^{47}$ Furthermore, the toxicity does not appear to be limited only to the muscle fibers. Haasters et $\mathrm{al}^{48}$ has reported that $0.5 \%$ bupivacaine has cytotoxic effects on human tendon stem cell/progenitor cells, while morphine had no effect on apoptosis or decreased cell survival. Both erythropoietin ${ }^{49}$ and $\mathrm{N}$-acetylcysteine ${ }^{50}$ may confer a protective action against bupivacaine-induced myocyte death.

\section{Discussion}

EXPAREL ${ }^{\circledR}$ has been found to be a more effective pain management treatment than standard bupivacaine in inguinal hernia repair, bunionectomy, hemorrhoidectomy, and breast augmentation surgery. There is a clear increase in efficacy in using EXPAREL ${ }^{\circledR}$ compared to using bupivacaine $\mathrm{HCl}$, and no significant difference in AEs has been reported. Furthermore, EXPAREL ${ }^{\circledR}$ is likely to cost patients less money than bupivacaine $\mathrm{HCl}$ due to diminished opioids usage and shortened hospital stays. However, caution should be taken when performing the cost-benefit analysis of EXPAREL ${ }^{\circledR}$ injection as the main pain management therapy. Both intraarticular and spinal injections should be cautioned due to potential toxic effects and permanent damage to cartilage and intervertebral disk cells. Granulomatous inflammation and myonecrosis have not been found to cause permanent longterm damage at normal EXPAREL ${ }^{\circledR}$ dosages. Furthermore, cardiotoxicity does not appear to be significant compared to bupivacaine $\mathrm{HCl}$. We conclude that EXPAREL ${ }^{\circledR}$ has potential value to decrease the length of hospital stay and increase patient satisfaction if used properly. 


\section{Acknowledgments}

Dr Zongbing You was partly supported by a grant from the Department of Defense (PC121647), two grants from the National Institute of General Medical Sciences (P20GM103518) and the National Cancer Institute (R01CA174714) of the National Institutes of Health, the Developmental Fund of Tulane Cancer Center, and Louisiana Cancer Research Consortium Fund. The content is solely the responsibility of the authors and does not necessarily represent the official views of the National Institutes of Health. Dr Zongbing You, Dr Michael J O'Brien, and Dr Felix H Savoie received a research grant from DePuy Mitek, Raynham, MA, USA, for a different study, which had no role in the preparation and submission of this manuscript. Mr Mark Lambrechts was supported by a summer stipend from the DeBakey Scholars Program of Tulane University School of Medicine.

\section{Disclosure}

The authors report no conflicts of interest in this work.

\section{References}

1. Myles PS, Williams DL, Hendrata M, Anderson H, Weeks AM. Patient satisfaction after anaesthesia and surgery: results of a prospective survey of 10,811 patients. Br J Anaesth. 2000;84(1):6-10.

2. Hanna MN, González-Fernández M, Barrett AD, Williams KA, Pronovost P. Does patient perception of pain control affect patient satisfaction across surgical units in a tertiary teaching hospital? Am J Med Qual. 2012;27(5):411-416.

3. Benyamin R, Trescot AM, Datta S, et al. Opioid complications and side effects. Pain Physician. 2008;11(Suppl 2):105-120.

4. Walder B, Schafer M, Henzi I, Tramèr MR. Efficacy and safety of patientcontrolled opioid analgesia for acute postoperative pain. A quantitative systematic review. Acta Anaethesiol Scand. 2001;45(7):795-804.

5. Odera GM, Said Q, Evans RS, et al. Opioid-related adverse drug events in surgical hospitalizations: impact on costs and length of stay. Ann Pharmacother. 2007;41(3):400-406.

6. Akhtar MI, Saleem M, Zaheer J. Wound infiltration with Bupivacaine versus Ketorolac for postoperative pain relief in minor to moderate surgeries. J Pak Med Assoc. 2009;59(6):385-388.

7. Leone S, Di Cianni S, Casati A, Fanelli G. Pharmacology, toxicology, and clinical use of new long acting local anesthetics, ropivacaine and levobupivacaine. Acta Biomed. 2008;79(2):92-105.

8. Tuominen M, Haasio J, Hekali R, Rosenberg PH. Continuous interscalene brachial plexus block: clinical efficacy, technical problems and bupivacaine plasma concentrations. Acta Anaesthesiol Scand. 1989;33(1):84-88

9. Klein SM, Grant SA, Greengrass RA, et al. Interscalene brachial plexus block with a continuous catheter insertion system and a disposable infusion pump. Anesth Analg. 2000;91(6):1473-1478.

10. Brown SL, Morrison AE. Local anesthetic infusion pump systems adverse events reported to the Food and Drug Administration. Anesthesiology. 2004;100(5):1305-1307.

11. Cocoran W, Butterworth J, Weller RS, et al. Local anesthetic-induced cardiac toxicity: a survey of contemporary practice strategies among academic anesthesiology departments. Anesth Analg. 2006;103(5): 1322-1326.

12. Richard BM, Newton P, Ott LR, et al. The safety of EXPAREL ${ }^{\circledR}$ (bupivacaine liposome injectable suspension) administered by peripheral nerve block in rabbits and dogs. J Drug Deliv. 2012;2012:962101.
13. Marcaine ${ }^{\mathrm{TM}}$ (bupivacaine $\mathrm{HCl}$ ) [prescribing information]. Lake Forrest, IL: Hospira Inc; 2009.

14. Drug pricing policy. San Francisco, CA: First Databank Inc; 2013. Available from: http://www.fdbhealth.com/policies/drug-pricingpolicy/. Accessed July 19, 2013.

15. Cohen SM. Extended pain relief trial utilizing infiltration of Exparel $\left({ }^{\circledR}\right)$, a long-acting multivesicular liposome formulation of bupivacaine: a Phase IV health economic trial in adult patients undergoing open colectomy. J Pain Res. 2012;5:567-572.

16. Clarkson CW, Hondeghem LM. Mechanism for bupivacaine depression of cardiac conduction: fast block of sodium channels during the action potential with slow recovery from block during diastole. Anesthesiology. 1985;62(4):396-405.

17. Chahar P, Cummings KC. Liposomal bupivacaine: a review of a new bupivacaine formulation. J Pain Res. 2012;5:257-264.

18. Baxter R, Bramlett K, Onel E, Daniels S. Impact of local administration of liposome bupivacaine for postsurgical analgesia on wound healing: a review of data from ten prospective, controlled clinical studies. Clin Ther. 2013;35(3):312-320. e5.

19. Viscusi ER, Sinatra R, Onel E, Ramamoorthy SL. The safety of liposome bupivacaine, a novel local analgesic formulation. Clin J Pain. Epub February 26, 2013.

20. Dasta J, Ramamoorthy S, Patou G, Sinatra R. Bupivacaine liposome injectable suspension compared with bupivacaine $\mathrm{HCl}$ for the reduction of opioid burden in the postsurgical setting. Curr Med Res Opin. 2012;28(10):1609-1615.

21. Haas E, Onel E, Miller H, Ragupathi M, White PF. A double-blind, randomized, active-controlled study for post-hemorrhoidectomy pain management with liposome bupivacaine, a novel local analgesic formulation. Am Surg. 2012;78(5):574-581.

22. Bramlett K, Onel E, Viscusi ER, Jones K. A randomized, double-blind, dose-ranging study comparing wound infiltration of DepoFoam bupivacaine, an extended-release liposomal bupivacaine, to bupivacaine $\mathrm{HCl}$ for postsurgical analgesia in total knee arthroplasty. Knee. 2012;19(5):530-536.

23. Smoot JD, Bergese SD, Onel E, Williams HT, Hedden W. The efficacy and safety of DepoFoam bupivacaine in patients undergoing bilateral, cosmetic, submuscular augmentation mammaplasty: a randomized, doubleblind, active-control study. Aesthet Surg J. 2012;32(1):69-76.

24. Bergese SD, Ramamoorthy S, Patou G, Bramlett K, Gorfine SR, Candiotti KA. Efficacy profile of liposome bupivacaine, a novel formulation of bupivacaine for postsurgical analgesia. J Pain Res. 2012;5: $107-116$.

25. Golf M, Daniels SE, Onel E. A phase 3, randomized, placebo-controlled trial of DepoFoam ${ }^{\circledR}$ bupivacaine (extended-release bupivacaine local analgesic) in bunionectomy. Adv Ther. 2011;28(9):776-788.

26. Gorfine SR, Onel E, Patou G, Krivokapic ZV. Bupivacaine extendedrelease liposome injection for prolonged postsurgical analgesia in patients undergoing hemorrhoidectomy: a multicenter, randomized, double-blind, placebo-controlled trial. Dis Colon Rectum. 2011;54(12): 1552-1559.

27. Gristwood RW. Cardiac and CNS toxicity of levobupivacaine: strengths of evidence for advantage over bupivacaine. Drug Saf. 2002;25(3): $153-163$.

28. de La Coussaye JE, Bassoul BP, Albat B, et al. Succinylcholine does not worsen bupivacaine-induced cardiotoxicity in pentobarbitalanaesthetized dogs. Can J Anaesth. 1992;39(2):192-197.

29. Huang YF, Pryor ME, Mather LE, Veering BT. Cardiovascular and central nervous system effects of intravenous levobupivacaine and bupivacaine in sheep. Anesth Analg. 1998;86(4):797-804.

30. Borgeat A, Ekatodramis G, Blumenthal S. Interscalene brachial plexus anesthesia with ropivacaine $5 \mathrm{mg} / \mathrm{mL}$ and bupivacaine $5 \mathrm{mg} / \mathrm{mL}$ : effects on electrocardiogram. Reg Anesth Pain Med. 2004;29(6):557-563.

31. Naseem A, Harada T, Wang D, et al. Bupivacaine extended release liposome injection does not prolong QTc interval in a thorough QT/ QTc study in healthy volunteers. J Clin Pharmacol. 2012;52(9): 1441-1447. 
32. Feldman HS, Arthur GR, Covino BG. Comparative systemic toxicity of convulsant and supraconvulsant doses of intravenous ropivacaine, bupivacaine, and lidocaine in the conscious dog. Anesth Analg. 1989;69(6): 794-801.

33. Richard BM, Ott LR, Haan D, et al. The safety and tolerability evaluation of DepoFoam bupivacaine (bupivacaine extended-release liposome injection) administered by incision wound infiltration in rabbits and dogs. Expert Opin Investig Drugs. 2011;20(10):1327-1341.

34. Chu CR, Izzo NJ, Coyle CH, Papas NE, Logar A. The in vitro effects of bupivacaine on articular chondrocytes. J Bone Joint Surg Br. 2008;90(6):814-820.

35. Chu CR, Coyle $\mathrm{CH}$, Chu CT, et al. In vivo effects of single intra-articular injection of $0.5 \%$ bupivacaine on articular cartilage. J Bone Joint Surg Am. 2010;92(3):599-608.

36. Wiater BP, Neradilek MB, Polissar NL, Matsen FA. Risk factors for chondrolysis of the glenohumeral joint: a study of three hundred and seventyfive shoulder arthroscopic procedures in the practice of an individual community surgeon. J Bone Joint Surg Am. 2011;93(7):615-625.

37. Anderson SL, Buchko JZ, Taillon MR, Ernst MA. Chondrolysis of the glenohumeral joint after infusion of bupivacaine through an intra-articular pain pump catheter: a report of 18 cases. Arthroscopy. 2010;26(4):451-461.

38. Piper SL, Kramer JD, Kim HT, Feeley BT. Effects of local anesthetics on articular cartilage. Am J Sports Med. 2011;39(10):2245-2253.

39. Liu S, Zhang QS, Hester W, O’Brien MJ, Savoie FH, You Z. Hyaluronan protects bovine articular chondrocytes against cell death induced by bupivacaine at supraphysiologic temperatures. Am J Sports Med. 2012;40(6):1375-1383.

40. Lee H, Sowa G, Vo N, et al. Effect of bupivacaine on intervertebral disc cell viability. Spine J. 2010;10(2):159-166.

41. Quero L, Klawitter M, Nerlich AG, Leonardi M, Boos N, Wuertz K. Bupivacaine - the deadly friend of intervertebral disc cells? Spine J. 2011;11(1):46-53.
42. Wang D, Vo NV, Sowa GA, et al. Bupivacaine decreases cell viability and matrix protein synthesis in an intervertebral disc organ model system. Spine J. 2011;11(2):139-146.

43. Moon JH, Kuh SU, Park HS, et al. Triamcinolone decreases bupivacaine toxicity to intervertebral disc cell in vitro. Spine J. 2012;12(8): 665-673.

44. Akbari MR, Amoli FA, Alhashemi LH, et al. Bupivacaine injection myotoxicity on extraocular muslces. A strabismus alternative treatment: extended histological changes induced in a rabbit model. Binocul Vis Strabolog Q Simms Romano. 2012;27(1):15-22.

45. Zink W, Graf BM, Sinner B, Martin E, Fink RH, Kunst G. Differential effects of bupivacaine on intracellular $\mathrm{Ca} 2+$ regulation: potential mechanisms of its myotoxicity. Anesthesiology. 2002;97(3):710-716.

46. Zhang C, Phamonvaechavan P, Rajan A, Poon DY, Topcu-Yilmaz P, Guyton DL. Concentration-dependent bupivacaine myotoxicity in rabbit extraocular muscle. J AAPOS. 2010;14(4):323-327.

47. Nouette-Gaulain K, Dadure C, Morau D, et al. Age-dependent bupivacaine-induced muscle toxicity during continuous peripheral nerve block in rats. Anesthesiology. 2009;111(5):1120-1127.

48. Haasters F, Polzer H, Prall WC, et al. Bupivacaine, ropivacaine, and morphine: comparison of toxicity on human hamstring-derived stem/ progenitor cells. Knee Surg Sports Traumatol Arthrosc. 2011;19(12): 2138-2144.

49. Nouette-Gaulain K, Bellance N, Prévost B, et al. Erythropoietin protects against local anesthetic myotoxicity during continuous regional analgesia. Anesthesiology. 2009;110(3):648-659.

50. Galbes O, Bourret A, Nouette-Gaulain K, et al. N-acetylcysteine protects against bupivacaine-induced myotoxicity caused by oxidative and sarcoplasmic reticulum stress in human skeletal myotubes. Anesthesiology. 2010;113(3):560-569.
Patient Preference and Adherence

\section{Publish your work in this journal}

Patient Preference and Adherence is an international, peer-reviewed, open access journal focusing on the growing importance of patient preference and adherence throughout the therapeutic continuum. Patient satisfaction, acceptability, quality of life, compliance, persistence and their role in developing new therapeutic modalities and compounds to

\section{Dovepress}

optimize clinical outcomes for existing disease states are major areas of interest. This journal has been accepted for indexing on PubMed Central. The manuscript management system is completely online and includes a very quick and fair peer-review system. Visit http://www.dovepress.com/ testimonials.php to read real quotes from published authors. 